\title{
Aktif ve Pasif Yurttaşlardan Oluşan Toplumlarda Planlama Süreci ve Plancının Rolü
}

\author{
Züleyha Sara Belge ${ }^{1}$ \\ ORCID: 0000-0003-0500-4847
}

Öz

Bu yazının amacı aktif ve pasif yurttaşlardan oluşan farklı toplum yapılarında ne tür planlama süreçlerinin ortaya çıkabileceği konusunda bir tartışma yapmaktır. Aktif veya pasif yurttaşlık, bu yurttaşların oluşturduğu farklı toplumsal yapı, bu yapı içerinde ortaya çıabilecek liderlik biçimleri, temsili veya katılımo demokrasi ve nasıl bir planlama sorusu bu yazının temel soruların oluşturmaktadır. Yurttaşlık temelli ortaya çıkan toplumsal yapı farklılıklarının planın meşruiyetini, uygulanmasını, örgütlenmesini ve planlama sürecini nasıl etkilediğine dair tartışmalar, Orta Doğu Teknik Üniversitesi, Şehir ve Bölge Planlama Doktora Programında Prof. Dr. İlhan Tekeli tarafindan yürütülen derslerde yapılan teorik tartışmalar ve değerlendirmeler çerçevesinde gelişmiştir. Bu bă̆lamda, yazının yöntemi temel kavramların çerçevesinin çizilmesi ve farklı örnekler üzerinden karşılaştırmalı değerlendirmeye dayanmaktadır. Bu değerlendirme sonucunda, sosyal, ekonomik ve kültürel yığılma noktalar olan kentlerde farklı planlama ve uygulama süreçlerinin kentli yurttaşlıkla ilişkili olarak oluştuğu görülmüştür. Sonuç olarak, ortaya koyulan farklı yurttaş davranışları, toplumsal yapı ve liderlik gibi etmenler dikkate alınarak planlamanın meşruiyeti, uygulanması, örgütlenme ve nasıl bir planlama sürecinin gerçekleşebileceğine dair öneriler geliştirilmiştir.

Anahtar Kelimeler: Aktif yurttaş, pasif yurttaş, demokrasi, planlama süreci

${ }^{1}$ Öğr. Gör. Dr., Mersin Üniversitesi, E-mail: zbelge@mersin.edu.tr

idealkent $\odot$ Kent Araştırmaları Dergisi (Journal of Urban Studies)

http://idealkentdergisi.com

Geliş Tarihi Received Date: 28.01.2020 Kabul Tarihi Accepted Date: 25.04.2020 


\title{
Planning Process and the Role of the Planner in Communities of Active and Passive Citizens
}

\author{
Züleyha Sara Belge ${ }^{2}$ \\ ORCID: 0000-0003-0500-4847
}

\begin{abstract}
The aim of article is to discuss what kind of planning processes could emerge in different community structures consisting of active and passive citizens. Active or passive citizenship, the different social structure created by these citizens, the leadership styles that emerging within this structure, representative or participatory democracy and what kind of planning approaches are the main questions of the article. Discussions on how the social structure differences that emerged based on citizenship affect the legitimacy, implementation, organization and planning process of the plan was developed within the framework of theoretical discussions and evaluations in the courses (Middle East Technical University, City and Regional Planning Doctorate Program) conducted by Prof. Dr. Ilhan Tekeli. In this context, the method of study is based on defining the basic concepts and comparative evaluation through different cases. As a result of these evaluations, it was observed that different planning and implementation processes occurred in cities with social, economic and cultural accumulation points in relation with urban citizenship. As a result, suggestions have been developed regarding the legitimacy, implementation, organization and what kind of planning process can take place by considering the factors such as different citizen behaviours, social structure and leadership.
\end{abstract}

Keywords: Active citizen, passive citizen, democracy, planning process

${ }^{2}$ Inst. Dr., Mersin University, E-mail: zbelge@mersin.edu.tr

idealkent @ Kent Araştırmaları Dergisi (Journal of Urban Studies)

http://idealkentdergisi.com

Geliş Tarihi Received Date: 28.01.2020 Kabul Tarihi Accepted Date: 25.04.2020 


\section{Yurttaşlık ve Demokrasi}

Tekeli (2010, s.91-92) insan haklarının evrensel olmasıyla birlikte genişleyen hakların beraberinde sorumluluklar getirdiğinin de altın çizmektedir. Başka bir ifadeyle, bir toplumdan, topluluktan ve bir aradalıktan söz ediyorsak orada "hak" kavramı söz konusudur. Bireyin eyleme koymak istediği, yapmak istediği, gerçekleştirmek istediği her eylem "hak" ile meşru olabilir. Birlikte yaşama ve bir arada olabilmek için belirlenen bu "hak" toplum tarafından tanınmalı ve toplumdaki her bir birey eğer hak sahibi olmak istiyor ve sahip olduğu hakların artmasını istiyorsa özgürlügün bu haklar ile geleceğini bilmelidir. Ancak, sorumluluğun da yine bu haklar ile artacağının bilincinde olmalıdır. Bu durumda, Martin (1993) yurttaşlık kavramıyla da ilişkili olarak hakların ve sorumlulukların tanımlanmasında Devlet ve/ya kurumsallaşmanın rolünden bahseder.

Demokrasi teriminin kökleri, Yunanca demos (halk) ve kratos (yönetim) sözcüklerine dayanmaktadır. Temel anlamıla demokrasi, yönetimde hükümdarların ya da sadece soylu sınıflarının değil, halkın olduğu bir siyasal düzendir. Ancak, çeşitli dönemlerde halk kavramının farklı anlamlarının olması nedeniyle, demokratik yönetim biçimleri de her dönemde farklılaşmaktadır. Başka bir deyişle, demokrasi, yönetimde halkın olduğu bir siyasal düzendir (Giddens, 2000, s. 939). Bu bağlamda, demokrasinin aldığı biçim, büyük ölçüde onun değerlerinin ve hedeflerinin nasıl anlaşıldığının ve öncelikli tutulduğunun bir sonucudur (Giddens, 2000, s. 897).

Barber (1995), siyaseti bir yaşam biçimi olarak incelemiş ve "güçlü demokrasi"nin kendi kendini yöneten yurttaşlar topluluğu" fikrine dayandığını belirtmiştir. Güçlü demokrasi kavramı içinde çatışma ve çoğulculuk barındırırken, araçsal, temsili ve liberal demokrasiye karşı geçerli bir alternatif sunar. Demokrasi sadece hedef odaklı değildir, sürecin de dikkate alınması gerekir. Bu durumu Barber (1995), "demokrasinin araç kadar amaç da olduğu önermesinden hareketle, siyasette varılmak istenen nokta (hedef) kadar gidişinde önemli olduğu, gidiş sırasında yolcular arasındaki ilişkinin de önemli bir etken olduğu" şeklinde açıklamaktadır.

Coleman ve Blumler (2009) güçlü demokrasinin enerji ve özerk sivil aktivite gerektirdiğine değinirler. Blaug'a göre demokrasi ikileminin anlaşılması için iki demokrasi modeli ele alınmalıdır. Bunların ilki yerleşik demokrasidir. Bu modelde mevcut kurumları "düzenli katılımı en üst düzeyde arttırarak ve yöneterek" korumak ve geliştirmek ön plandadır. Yerleşik demokraside etkili ve etkin olma sadece kurumlar aracılığıyla başarılabilir. Bu durum demokratik devletin 
merkezi temsil yapısının uyumlu olması için gereklidir. İkincisi ise eleştirel demokrasi modelidir. Bu modelde ise yerleşik demokrasiden farklı olarak etkinlik kolektif bağlılık söz konusudur. Burada katılımın kurumsallaşması radikal enerjiyi ehlileştirmek için bir girişim olarak görülmektedir (Blaug, 2002 aktaran Coleman ve Blumler, 2009). Coleman ve Blumler ise demokratik katılımın siyasi sonuçlar üzerinde anlamlı bir etkiye sahip olması için kapsayıcı ve sorumlu kurumlara ihtiyaç olduğunu belirtirler. Çünkü bu şekilde ortaya çıan etkileşim yurttaşlar ve seçilenler için bir alan (space) yaratabilir. Böylece temsili demokrasi kamusal söylev ve katılıma açlabilecektir.

Bu şekilde kurgulanan bir katılım biçimi ile demokrasi anlam kazanacaktır. Siyaset alanında var olan "eylem, kamusallık, zorunluluk, makul olma, çatısma ve bağımsız bir temelin yokluğu" gibi koşullar, güçlü demokrasi ile farklı bir şekilde ele alınarak katılımın, müzakerenin söz konusu olduğu siyasal durumlar ile incelenmektedir. Doğrudan demokrasi türü olan güçlü demokrasi; kamusallıklar yaratır ve hiç yoktan toplumsal bağlar kuran atomik bireyler kurgusunu reddeder. Aynı zamanda bireylere kendilerini tanımlamaları için sosyal topluluklar ortaya atan ortakçı ve dayanışmacı düşünceleri reddeder. Çünkü demokrasinin temelinde kayırma ve yandaş ilişkisi yoktur. Güçlü demokrasi, öz olarak bir yurttaşlar topluluğu nasıl yaratılabilir sorusu ile ilgilenir, kamusal seçimde zorunluluk hissine karşı duyarlıdır. Güçlü demokrasi için eylemlilik ve sorumluluk siyasetin merkezinde temeldir. Güçlü demokrasinin başka bir şartı ise katılım esaslı ve özerk seçim yapabilen yurttaşlar gerektirmesidir.

Bireysel istem, katılım yoluyla kendi yasalarını oluşturma fikrinin özüdür. Yaklaşık çözümler arayarak kendi yasalarını oluşturma eylem kümeleri, güçlü demokrasi fikrinin özünü oluşturur. Burada makul olma soyut bir siyaset önkoşulu olarak değil, güçlü demokratik siyasetin doğurduğu bir tutumdur. Siyaset alanında yer alan çatışma yerine burada katılım, tartı̧̧ma ve yurttaşlık eğitimi ile çatışmayı iş birliğine dönüştüren bir siyaset esastır. Her bireyin düşünce ve inançlarına eşit bir başlama yeri verir ve meşruiyeti kamusal tartışma ve eylem süresince olanlarla ilişkilendirir. Bu bağlamda, güçlü demokrasi söz söyleyen ve bunu eylemler ile ortaya koyan ve aktif olarak rol alan yurttaş ile mümkündür. Güçlü demokrasinin ortaya koyulabileceği en temel yurttaşlık biçimi ise hem nüfus hem sosyoekonomik yığılma hem de mekânsal yoğunluk dikkate alındığında kent yurttaşlığıdır. 


\section{Kent Yurttaşlığı}

Aristoteles, "yurttaş"1 fikir vermeye ve kamu alanında görev almaya katılan kişi olarak tanımlamaktadır (Aristoteles, 1981 aktaran Held, 1998). Antik Yunan da yurttaşlık özgür, yetişkin ve toprak sahibi erkekler de kamu alanında görev almak anlamına gelmektedir. Held bu tanımın iki şekilde değerlendirilmesi gerektiğini belirtir, birincisi bu tanımın kamu görevlileri ve temsilciler dışında antik Atina'da modern demokrasi bağlamında yurttaş tanımına uygun bireyler bulmakta zorlanılması (Held, 1998), ikinci olarak da bu tarif edilen Yunan yurttaşlık anlayışının ilk süreçte ve sonrasında az sayıda toplulukta yer almasıdır (Bernal,1987 aktaran Held, 1998, s. 37). Antik demokrasilerde insanlarm politik bir düzenin aktif yurttaşları olabilecekleri fikri çok uzaktır, aksine bu sistemde insanlar liderin tebaası olarak yer alırlar (Held, 1998, s. 38).

Giddens (2000, s. 893) geleneksel devletlerde, kral ya da imparator tarafindan yönetilen nüfusun, onları yönetenlerle ilgili pek az farkındalık ya da onlara yönelik pek az ilgi gösterdiğini belirtir. Bu durumda, yurttaşların hiçbir siyasal hakları ya da etkileri de bulunmamaktadır. Olağan olarak, yalnızca güçlü sınıflar ya da daha varlıklı topluluklar topluca siyasal bir gruba ilişkin olma duygusu hissederdi. Buna karşıt olarak, modern toplumlarda, bir siyasal düzenin sınırları içerisinde yaşayan insanların çoğu, ortak hakları ve ödevleri olan ve kendilerine bir ulusun parçası gözüyle bakan yurttaşlardır. Siyasal sığınmacı ya da "devletsiz" olan kimi insanlar olmakla birlikte, bugün dünyada neredeyse herkes belirli bir ulusal siyasal düzenin üyesidir.

Günümüzde sosyal medyada veya günlük yaşantımız içinde; tüketici olarak, dinleyici olarak veya kişisel kimliğimiz de dahil olmak üzere birçok sosyal kimliğimiz mevcuttur ve yurttaş olma rolü ise bu kimliklerin daha karışık durumlarından birisidir. Yurttaş olmak bir siyasi topluluk -bireyin kendi oluşturduğu değil- içinde yabancılarla bir ilişkiye girmektir. Yurttaşlar olarak, birbirimizi bilmemiz veya anlamamız beklenmez, ancak, politik yapıyı oluşturmak için, bir arada yaşama normlarına ve kurallara uymamız beklenir (Coleman ve Blumler, 2009).

Bu çerçevede, Bauböck (1994) bazı insanların kendilerini dünya vatandaşı olarak gördüğünü belirtir. Kendilerini bir devlete veya ulusa bağlı hissetmezler, ancak pasaporta ihtiyaçlanı vardır. Uluslararası politik sistem, dünyayı farklı ulusal sınılara böldüğü gibi insanlığı da farklı yurttaşlıklara böler. Anayasal ülkelerde yaşayanlar, anayasada öngörülen haklara ve politik katılım hakkına sahip olabilmeleri için o ülkeye yurttaşlık bağı ile bağlı olmalıdırlar. 
Bauböck'ün ortaya koyduğu yurttaşlık küreselleşme ile tartışlan bir konu haline gelmiştir. Ancak, mekânsal olarak incelendiğinde yerel, bölgesel, ulusal, uluslararası ve ulusüstü yurttaşlık biçimleri ortaya çıkabilmektedir. Her düzeyin belirli sorumlulukları ve hakları bulunmaktadır. Bu durumda, aktif yurttaşlık çok kimlik, çok hak ve dolayısıyla çok sorumluluk gerektirmektedir (Bauböck, 1994).

Coleman ve Blumler (2009) yurttaşlı̆̆ın akışkan ve yaygın tartışmalı bir kavram olduğunu belirtir ve bu kavram üç biçimde değerlendirilebilir. Birincisi, bir politik topluma (genellikle ulus-devlet) ve onun yürürlükteki yasa, düzenleme ve geleneklerine bağlı resmi yurttaşlık kavramıdır. İkincisi, birinci tanıma çok yakın bir siyasi yurttaşlıktır, ancak birincisinin kuralcı ve yasaklayıcı normatif şartlarını aşmaktadır. Üçüncüsü ise, etkin, aktif yurttaşlıktır. Öncelikle sivil aidiyet, bağlılık ve dayanışmayı harekete geçirmekle ilgilenir.

Başka bir tanımla, özü politik eylem olan aktif yurttaş, siyasal insan, siyaset yapan birey- "homo politicus" olarak değerlendirilmelidir. Held, "siyasal insanhomo politicus"un antitezi olarak "homo credens" i gösterir (Held, 1998: 38). Tarihte birçok defa karşı karşıya gelen siyasal insan (homo politicus) ve inanan insanın (homo credens-Held tarafından Hristiyanlığa inanan insan olarak değerlendirilmiştir) farklı siyaset anlayışına sahip olduğu ve bu bağlamda farklı toplumsal yapılar oluşturduğu açıktır. Siyaset yapan siyasal insan yani aktif yurttaş için ise demokrasi inancı esastır.

Sarıbay (1996) ise şehir-devletinden başlayıp günümüze kadar geçen sürede "yurttaş" kavramıyla kastedilen iki farklı anlayışın etkili olduğunu savunur. Bunların birincisinde, yurttaşlı̆̆ bir görev, bir sorumluluk, gururla kabul edilmiş bir yük olarak tanımlar. İkincisinde ise, yurttaşlı̆̆ bir statü, bir yetki, bir hak veya pasif şekilde kullanılan haklar manzumesi olarak görür. Birinci anlayışta yurttaşıık hayatımızın çekirdeğini oluşturur; ikincisinde hayatımızın dışsal çerçevesi olarak belirir. Hayatımızın çekirdeği olarak yurttaşlıkta aktörlerin bir diğerine sıkı sıkıya bağıllığı söz konusudur. Dışsal çerçeve olarak yurttaşlıkta bu sıkı bağa rastlanmaz; aktörlerin ayrı bağlılıkları vardır. Bu itibarla, yurttaşlı̆̆ bir görev olarak tanımlayan anlayış yurttaşı aynı zamanda siyasal hayalin baş aktörü olarak görür; o hem kanun yapıcıdır hem de kendi günlük işlerinin yönetimini ifa eder. Oysa statü olarak yurttaşlık anlayışında kanun yapma ve yönetim başkalarının işidir

Aktif yurttaş devamlı tartışma ortamı sağlar, müzakere önceliklidir. Başka bir deyişle, sadece oy vermekle kalmaz, oy vermenin bir tercih belirtme arac1 olduğunun bilincinde olarak "katılımın, katılımcılar gerektiren dinamik bir 
yapı ve tüm kamusallıkları değerlendirerek oluşan yaratıı bir süreç" olduğunun bilincindedir. Aktif yurttaş doğrudan demokrasi türü olan güçlü demokrasiyi kabul eder çünkü burada katılımc tarzda siyaset söz konusudur. Barber (1995), güçlü demokrasi için "gerçek ve tam anlamıyla demokratik olan tek biçimdir" ifadesini kullanmaktadır. Pasif yurttaşlar temsili demokrasiyi kabul ederken aktif yurttaşlar özyönetimi kabul ederler. Barber'in (1995) değimi ile özyönetim gündem oluşturma, tartısma, yasama ve siyaset yapma süreçlerine yurttaşların devamlı katılımına olanak sağlayan kurumlar tasarlanması ile gerçekleşebilir.

Şahin ve Altun (2019, s. 1808) aktif yurttaşlığın kent yurttaşlığıyla birlikte değerlendirilmesi gerektiğini belirtmektedirler. Kentlerin, yukarıda belirtildiği üzere sosyal, kültürel, ekonomik ve dolayısıyla siyasi hayatın merkezinde yer alması nedeniyle kent mekânı ve kent yaşamı sürekli bir dönüşüm-değişim içerisindedir. Bu nedenle, siyasal yaşam, sivil yaşam, sosyal yaşam ve demokratik-kültürel değerler kentli yurttaşlığın bağlamını belirler (Şahin ve Altun, 2019: s. 1820-21).

Bu durumda, kentli yurttaşın kentsel değişim ve dönüşüm içerisinde aktif olabilmesi sosyal, kültürel ve ekonomik hayatı ile doğrudan ilişkilidir. Diğer yandan, kentsel mekânın değişim ve dönüşümünde kentli yurttaşın aktif olabilmesi, yurttaşın yukarıda bahsi geçen ilişkilerinden bağımsız olarak planlama sürecinin örgütlenmesi ve işletilmesiyle de ilişkilidir.

\section{Planlama Sürecinin Örgütlenmesi}

Planlama sürecinin örgütlenmesinde, aktif ve pasif yurttaşlı̆̆ın etkilerinin daha net anlaşılabilmesi için, iki farklı toplum varsayımı üzerinden bir değerlendirme yapılması yerinde olacaktır. Varsayım olarak bir toplum yalnızca aktif yurttaş topluluğu bir diğeri ise pasif yurttaş topluluğu olduğunu kabul edersek, daha önceki bölümlerde vurgulanan çerçevede, aktif yurttaşlardan oluşan toplumda her bir yurttaşın kendisi siyasetçidir, siyaset yapar. Bireyin siyasetin içinde aktif bir şekilde yer alması ve kendini temsil etmesi doğrudan demokrasi anlayışı içinde güçlü demokrasi ile mümkündür. Güçlü demokrasi anlayışı barındıran aktif toplum, yaratıcı, müzakereci, katılımı esas alan hayal gücü geniş bir toplumdur.

Diğer taraftan bir temsilci ile siyasetin içinde olan, temsil edilmesi gereken bir birey gibi hareket eden toplum ise temsili demokrasi anlayışı ile hayatını sürdürür. Pasif yurttaş toplumunun benimsediği temsili demokrasi; otoriter, 
hukuki ve çoğulcu demokrasi olarak 3 türde incelenebilir. Her bir türde ise karşımıza şu çımaktadır; temsil; özgürlük, eşitlik ve toplumsal adalet ile bağdaşmaz. Çünkü bu anlayış siyasal iradeyi başkasına devreder ve kişisel özerklik yitirilir. Temsili demokrasi anlayışı bugün dünyanın birçok yerinde yaygın bir yönetim sistemidir. Çoğunluğa endekslenmesi azınlığı ve azınlık haklarını yok sayarak farklı fikirlerin ve çeşitliliğin hatta coşkunun önünde önemli bir engel olarak karşımıza çıkar. Pasif toplumda benimsenen temsili demokrasi anlayışı paternalist, kalıplar içine sıkışmış ve sınırları belirlenmiş, bir toplum oluşumuna neden olacaktır, bunun en büyük sebebi ise bireyin temsile ihtiyaç duyması ve bir başkasının onun için en iyiyi bildiğini kabullenmesi ile ortaya çıkacaktrr.

Tekeli (2016) kent yığılmasının niteliklerinin pasif yurttaşlardan oluşan bir toplum ile aktif yurttaşlardan oluşan bir toplum da büyük farklılıklar yaratmasından söz etmektedir. Modernitenin varsayımlarının doğal uzantısı olarak görülebilecek olan, pasif yurttaşların oluşturacağı bir kentsel yığılmanın önemli ölçüde bireyin tercihlerini geri plana iterek yabancılaştırılması durumu değerlendirildiğinde; postmodern dünyanın demokrasi arayışları içinde pasif yurttaşın yetersiz kalacağı görülmektedir. Böylece, özel alanına hapsedilemeyen, kamusal özne olma talebini canlı tutan aktif birey ortaya çıkacaktır. Kamusal özne olan birey, toplumda var olan projelere hapsolmayacak, onun yeniden biçimlenmesinde sözü olmasını isteyecektir. Gerçek, sahici (authentic) toplumdan ancak o zaman söz edilebilir (Tekeli, 2016, s. 53)

Birch (1993) ise pasif toplum için de katılımın esas olduğunu, katılımın demokratik olsun ya da olmasın her devletin araçsal gerekliliği olduğunu, çünkü katılımın insanların zihinlerinde yönetimin meşruiyetini oluşturduğunu belirtir. Ona göre siyasi reformlardan en fazla fayda sağlayacak olan eğitimsiz ve dar gelirli gruplar siyasete en az katılımı sağlamaktadır. Bu durum pasif toplumun gerçeğidir. Birch(1993), siyasi katılımın temel biçimlerini sınıflamıştır. Pasif yurttaşlar sadece ulusal seçimlerde veya referandumlarda oy vermekle yetinirken, aktif yurttaşlar seçimlerde aktif rol alırlar, siyasi bir partiye, gruba veya danışma komitelerine üye olur, protesto ve gösteri yapar, sosyal politika da istemci olur veya yerel topluluk hareketlerine katılır. Aktif yurttaşlığın özü yereldeki hakların savunması ile başlar.

Bu noktada, başka bir olgu ise liderlik sürecinde karşımıza çıkmaktadır. Pasif yurttaş topluluğunda oluşan lider kendisini başkası için en iyiyi bilme tekeline sahip ve başkasının iyisini bilmek, bunu hak görmek olarak bir yol çizebi- 
lir. Bu şekilde oluşan bir liderlik sürecinde, güçlü olan kendi tercihlerinin toplumun tercihleriyle özdeşleştiren ve bunu uygulamaya gücü olan olarak tanimlanabilir.

Bu durumda, liderlik kavramının daha detaylı tartışılması ve farklı boyutlarıyla ele alınması yerinde olacaktır. Basit bir tanımla, lider olacak kişinin deneyim, vizyon, motivasyon, bilgi ve güç bakımından diğerlerinden farklı olması gerekmektedir ve bu farklılıklar liderin meşruiyetini sağlar. Bu yapı içerisinde lider, liderliğini yaptığı topluluk içerisinde kontrol mekanizmasını oluşturmaktadır. En temel olarak liderliğini yaptığı topluluğa misyon ve vizyon tanımlar ve ortaya koyduğu misyon ve vizyon için toplumun geri kalan kısmını motive edip yönlendirir ve topluluk içerisinde hem kendisine hem de birbirlerine güven sağlar. Bu çerçevede, liderin bir diğer önemli rolü, konumu ise liderlik ettiği grubu temsil etme durumudur.

Bu çerçevede, önemli bir kavram olarak ideoloji, liderin kendisini izleyenlerle ilişkisini kurmakta kendi dayandıracağı ön kabullerin söylemi (Tekeli, 2016) olarak kabul edilebilir. İdeoloji ile bilimsel bilgi iç içedir ve ideoloji yeni bilgi ile yeniden formüle edilir. İnsanlar ideolojiler ile eylemlerini şekillendirirler. Bu süreçte ideoloji yol göstermek için kullanılır ve gösterdiği yol çalıştıkça, işe yaradıkça değişmez, ancak ideoloji izlenerek gerçekleştirilen eylemlerde yanılg1 varsa ideoloji yeniden kurulur, ya da yeniden yön verilir. Melucci (1996) ise bu durumu şöyle açklar; ideoloji toplumsal hareketleri anlamada anahtar analitik bir seviyedir.

Toplumsal hareketle ilişkili olarak ideolojinin iki boyutu söz konusudur. Bunların birincisi "ideoloji bir bütünleşme işlevi taşımaktadır", ikincisi ise "çevreyle ilgili stratejik işlevi vardır". Yani ideoloji durgun değildir dinamiktir ve gerilimlerden çatışmalardan etkilenir. Bu açıdan baktığımızda ideolojinin duruma göre değiştiğini, başarısızlık ile yeniden tanımlandığını anlayabiliriz. Mevcut durum ve başarısızlık ideolojinin yeniden biçimlenmesini gerektirir. Başarı ise o ideolojinin işlediğini ve doğru yöne gittiğini ortaya koyabilir.

Getimis ve Grigoriadou (2005), liderlerin içlerinde yer aldıkları topluluğun yapısına ve davranış biçimlerine göre farklılıklar gösterdiğini belirtmektedir. Liderler toplum içerisinde güçlü bir konumda yer alabileceği gibi ortak çalışma süreçlerini yönlendiren, toplum içerisinde yer alan diğer bireylerin de kendi hayat projelerini gerçekleştirebilmelerine olanak sağlayan yön gösterici veya kolaylaştırıcılar olabilir. Yukarıda hak tanımında belirtildiği üzere, her hak beraberinde bir sorumluluk getirir, liderlik ise çok fazla hak sahibi olmakla beraber daha fazla sorumluluk anlamina gelmektedir. Bu durumda, liderin elde et- 
tiği haklarla tek söz sahibi mi olacağı, yoksa toplumun tamamının hayatını kolaylaştıracağı o toplumun aktif mi yoksa pasif yurttaşlardan mı oluştuğuna bağlıdır. Başka bir ifadeyle, lider özelliklerini ve farklılıkların koruyabildiği sürece liderlik etmeye devam eder, ancak ortaya koyduğu öngörüler ile konumunu kaybetmeye başladığında, liderliğini de kaybetmesi gerekmektedir.

Tekeli (2016) plana, planlamaya ve kente dair siyasal parti yandaşlı̆ından kaynaklanan, yüzeysel değerlendirmeler ve yaşamdan aldığı doyumu pasif bir tüketici mantığına indirgeyen bir yaklaşımın rahatsızlık verici olduğuna değinmektedir. Bunun temelinde ise birinci sınıf bir demokrasinin güçlü bir yerel demokrasi ile mümkün olduğunu savunmaktadır. Güçlü bir yerel demokrasinin kurulması durumu büyük oranda aktif yurttaşlık anlayışının benimsendiği bir toplumsal süreç ile mümkündür. Tekeli'ye göre yerelde oluşturulabilecek bir demokrasi başarısının, yaşadığımız kent üzerinde doğurucu bir konuşma biçimi geliştirilmesi ile mümkündür. Bu bağlamda, öncelikle aktif yurttaşların, gelişmiş bir STK'lar ağının ve sağlıklı yerel bir kamu alanının bulunması ile mümkün olan örgütlenmiş bir yerel demokrasi ve bununla paralel işleyecek kentler üzerinde doğurucu bir konuşma biçiminin geliştirilmiş olması gerekmektedir (Tekeli, 2016, s. 170).

Aktif yurttaşlardan oluşan toplum ile pasif yurttaşlardan oluşan toplumlar da en temel farklılık yönetimde söz sahibi olmak ile ilişkilidir. Pasif yurttaşların çoğunlukta olduğu toplumlarda, lider elde ettiği tüm hakları fazlasıyla kullanarak konumunu korumaya çalışır ve bunu sağlayabilmek için diğerleri üzerinde baskı kurar. Bu nedenle, demokraside liderlik bazı durumlarda tamamen reddedilebilir, ancak demokratik liderliğin de bir liderlik çeşidi olması göz ardı edilmemelidir. Lider demokrat olursa demokratik liderliği yapabilir ve bunu sürdürebilir. Demokratik liderlikte; lider, liderin tüm takımı ve arkadaşları da demokratik olmalıdır. Demokratik liderliğin en büyük başarısı ve göstergesi de liderliği devredebilmektir. Daha açık bir ifadeyle lider, stratejiyi lider yapar. Her zaman çalışmaz ancak stratejik karar üretir. Üretilen bu karar, liderlik ettiği aktif yurttaşların ortak hayali veya yaşam projesidir. Bu proje tüm toplumun kaderini belirleyecek bir strateji olabileceği gibi, daha küçük sivil toplum kuruluşlarının hayata geçirmek istedikleri projeler veya yaşam biçimleri olabilmektedir. Aktif yurttaşlardan oluşan topluluklarda, lider, misyonunu tamamladığı zaman rolünü teslim eder veya paylaşır.

$\mathrm{Bu}$ yapı içerisinde nasıl bir planlama sorusu bu yazının temel sorusunu oluşturmaktadır. Aktif veya pasif yurttaşlık, bu yurttaşların oluşturduğu farklı toplumsal yapı, bu yapı içerinde ortaya çıkabilecek liderlik biçimleri, temsili 
veya katılımcı demokrasi ve nasıl bir planlama süreci olduğu birlikte değerlendirilmelidir. Aktif veya pasif yurttaşlık temelli ortaya çıkan toplumsal yapı farklılıkları planın meşruiyetini, uygulanmasını, örgütlenmesini ve planlama sürecini doğrudan etkilemektedir.

Tekeli'ye (2016) göre, kent planlama bir demokrasi projesidir. Aktif toplumun ve pasif toplumun hangi biçimlerde ortaya çıktıkları ve hangi meşruiyet çerçevesine dayandırıldıklarını incelemek gerekir. Bu iki toplumda yürütülen kent planlaması, liderlik süreçleri ve toplumun kendisi karar mekanizmaları açısından meşruiyetini nereden alır?

Güçlü demokrasi ve aktif yurttaşın planlamada rolünü anlamak için meşruiyet kavramının ele alınması gerekir. Meşruiyet kavramı çok boyutlu bir kavramdır. Beetham (1991), meşruiyetin üç şartı olduğunu bunların, gücün kanunlara ya da sözleşmelere istinaden, kurallar çerçevesinde uygulanması gerektiği, kuralların yöneten ile yönetilenlerin ortak inançlarına dayanması gerektiği, meşruiyetin yönetilenlerin açık rızasına dayanması gerektiğini belirtmektedir. Bu üç unsur meşruiyetin farklı bir yönüne odaklanır, birincisi kurallara vurgu yaparken, ikincisi inançların önemine değinmekte, üçüncüsü de eylemlere odaklanmaktadır. Güç ilişkilerinin ahlaki ve normatif yapısı meşruiyet ile oluşur, bu aşamada meşruiyet iktidar sahibi ile kitle/toplum arasında ahlaki bir iş birliği zemini oluşturur ve esas olarak meşruiyet toplumsal yapıyı belirler. Her toplumun kendine ait kuralları vardır ve gücün uygulanması ve erişimi toplumun kendi toplumsal kurallarına göre belirlenir ve buna göre uygulanır. Gücü ise meşruiyetten ayıramayız, bunun sebebi ise gücün ve meşruiyetin aynı anda oluşmasıdır.

Bu çerçevede öncelikli olarak planlamanın meşruiyeti açısından bir değerlendirme yaptığımızda, pasif toplumda planlama meşruiyetini devletten ya da planı yapan kurumun gücünden alır. Planı yapan- yaptıran, planın yapılmasına olanak sağlayan ne kadar güçlü ise planın uygulanabilirliği o kadar fazla olur. Pasif toplumda, planclar teknik uzman olarak görev yaparlar ve kentleri tam olarak belirlenmiş sistemler olarak kabul ederler yani modernist bir bakış açısı ve determinist, belirlenimci bir yaklaşım vardır. Planlama fiziki plan olarak ortaya çıar çünkü bu toplumda müzakere ve katılım söz konusu değildir. Pasif topluluktan oluşan toplum lidere ihtiyaç duyar. Oluşan örgüt müzakere ortamı olmadan karar verme yetkisini kendinde görebilir. Böyle bir süreçte kenti anlamaya çalışan bir planlama anlayışı değil fiziksel bir planlama anlayışı doğar. Plancı bu ortamda tek karar verici olabilir, her şeyi değerlendiren, karar veren plancı olabilir. Pasif toplumda gücü olan her şeyi yapabilir, ancak her yaptığı meşru değildir. Bir liderin yönlendirdiği planlama süreci örneği olarak 
Albert Speer tarafından özellikle Berlin kenti özelinde hazırlanan ve uygulanan planlar, liderin gücünü göstermesi amacıyla anıtsallığı ön plana çıkarması ve toplumun geri kalanı üzerinde güç gösterisi niteliğinde olması nedeniyle pasif yurttaş toplumu üzerine önemli bir planlama örneğidir (Helmer, 1985, s. 39 aktaran O'Donnell, 2006, s. 219).

Birey gözlemlediği, duyduğu ve algıladığı kadarını gerçek ile bağdaştırır ve bireyin gerçeği duyduğu, bildiği, okuduğu ve gördüğü ile sınırlı kalmaktadır. Tekeli (2009)'ye göre yaşantımızda gerçeğin çok az bir parçasını gözleriz veya duyarız. Örnek olarak büyük ya da küçük, insan bulunduğu mekânı nasıl yorumluyorsa öyle algilar. Toplumdaki farklı sinfflarda ve topluluklarda yer alan kişiler gerçeği farklı algılayacaklardır, demek ki gerçekte birçok yönlülük vardır. Eğer gerçek objektif olarak tanımlanmak isteniyorsa bu çok yönlülüğ̈̈ ifade edebilmelidir. Bu çok yönlülüğü kavrayabilmekte imgeleme düşen rol önemli olmaktadır. Bir kişi devamlı olarak kendi günlük işlerinin dar çerçevesi içinde kalırsa, kendi durumuna karşı soru soran bir tavır takınmayacaktır. Kendisinin gerçekte daha büyük bir sistemin parçası içinde olduğunu algilayamayacaktır. Ancak belirli bir kriz anında kendisini, algıladığı çerçevenin dışını hissedebilecektir. Bu görüş genişlemesi ise kendi deneyinin verdiği imkân ölçüsünde sinırlı olacaktır (Tekeli, 2009, s. 101). Bu değerlendirme ile diyebiliriz ki, temsili demokrasi örneklerinde gördügüumüz gibi çok oy alan her konuda kendi isteğini uygulama ve azınlıkta kalanı yok sayma gücünü elde etmektedir. Bu yapının başka bir nedeni ise, tek merkezden yönetilen bir toplumun yapısı nedeniyle, yerel politika olamaması ve yerel gündem oluşturulamamasıdır. Bu duruma aktif yurttaşlığı en temel çıkış noktası olan yerelde bir kapasite yetersizliği neden olmaktadır. Bilgi ve deneyim eksikliği, beraber iş yapabilme, müzakere ve ortak karar verebilme gibi süreçlerin yetersizliği yerel kapasite, dolayısıyla aktif yurttaşlığa olanak sağlamamaktadır.

Bu bağlamda, yetkinin tek merkezde olması durumunda, merkez her ne kadar planların yapılmasını yerele bırakıyormuş gibi gözükse de hem yasal yönetsel çerçeve ile hem de üst ölçekli kararlar ile yerelin karar verme araçları s1nurlanmaktadır. Bu süreç içerisinde en önemli araç olarak planların kademeli birlikteliği ilkesi kullanılmaktadır. Temelde ülkesel, bölgesel veya kentsel ölçekte genel geçerli gelişme stratejileri ve koruma-kullanma ilkelerinin belirlenmesi gereken üst ölçekli planlar, Türkiye'de Bakanlıklar aracilığıyla arazi kullanım planları olarak hazırlanmaktadır. Esnekliği olmayan ve uzun erimli hazırlanan planlar, Damokles'in kılıcı gibi yerel otoritelerin üzerinde durmakta ve tüm süreci kontrol altında tutmaya çalışmaktadır. Yerel yönetimler tarafından geliştirilen plan kararları ise geçersiz kalabilmektedir. 
Bu duruma örnek olarak, İstanbul Metropolitan Planlama süreci değerlendirilebilir. İstanbul kentinin planlama deneyiminde merkezi otorite tarafindan verilen kararlar her zaman belirleyici olmuştur. Bu durum, 1956-1960 arasında Adnan Menderes tarafından yönlendirilen Tarihi Yarımada içerisindeki ana caddelerin açllmasında ve 1970-1973 döneminde Süleyman Demirel'in bir projesi olarak ortaya çıkan Boğaz Köprüsü ve Çevre Yollarında görülmektedir (Tekeli, 1991, s. 16). Benzer etkileri günümüzde de izleyebilmekteyiz. İstanbul Büyükşehir Belediyesi bünyesinde oluşturulan çok geniş danışman kurulu ve çok disiplinli planlama ekibi tarafından, katılıma bir çerçeve de yaklaşık 5 yıllık bir çalışma süresi sonrasında hazırlanan 1/100.000 ölçekli İstanbul Çevre Düzeni Planı, 13.02.2009 tarih ve 103 sayılı Belediye Meclisi kararıyla kabul edilmiş ve 15.06.2009 tarihinde Başkanlık tarafından onaylanmıştır. Çevre düzeni planında, sürdürülebilirlik ilkeleri çerçevesinde Marmara Denizi boyunca doğubatı doğrultulu çok merkezli ve kademelenmiş merkezler ile sıçrayarak bir gelişme öngörülmüştür. Mutlaka korunması gereken orman ve su kaynaklarının yer aldığı kuzey kesiminde ise gelişmenin kontrol altına alınması yönünde plan kararları geliştirilmiştir. Kentin batısında, Silivri yakınlarında ise üçüncü ticari havalimanı öngörülmüştür (IBBB, 2009). Günümüzde ise, kentin kuzeyinde inşası tamamlanmış olan İstanbul Havalimanı, Yavuz Sultan Selim Köprüsü ve çevre yolları tamamen yürürlükteki 1/100.000 ölçekli Çevre Düzeni Planundan bağımsız olarak gerçekleşmiştir.

Bu bağlamda, pasif yurttaş planlama sürecine müdahil olmaz, olamaz. Ancak, Türkiye'de imar planında olduğu gibi kendini ilgilendiren bir durum var ise plan askı süreçleri içerisinde mülkiyet hakkı üzerinden tartışma yürütür. Daha açık bir ifadeyle, planlama sürecine katılım, ancak planlama sürecinin son aşaması olan onay aşamasında mümkün olabilmektedir. Bu noktadaki katılımın içeriği ise genelde sadece mülk sahiplerinin kendi mülklerine ve/veya komşu mülklere ilişkin yapılaşma koşulları, arazi kullanım kararı veya ulaşım öngörüleri üzerinden gerçekleşmektedir. Bu sürecin bir diğer problemli yanı ise, katılımda planlama sürecinin temel ilkesi olan kamu yararı ilkesinin göz ardı edilmesidir. Planlara yapılan itirazlarda sosyal ve teknik donatı alanlarının dengeli ve hakkaniyetli dağılımı yerine, yapılaşma koşulları ön plana çıkmaktadır. Planlama alanı içerisinde kimse kendi mülkü üzerinde eğitim tesisi, park, sağlık tesisi gibi donatıların olmasını istemez. Ancak, her mülk sahibi komşu parselinde bu tip sosyal donatiların olmasin tercih eder.

Aktif toplumda ise planlama müzakere ile oluşur. Katılım planlama sürecinin son aşamasında değil, bilgi toplama ve karar verme süreçleri ile eşzamanlı ve güdümlü devam etmektedir. Böyle bir ortamda her bir bireyin söz hakkı 
vardır. Hak kavramı bir toplumda bireyin yapmak istediklerinin meşru yolu olarak görülür. İnsan hakları burada en üst haklardır ve meşruiyet buradan gelir. Stratejik planlama ve demokratik planlama bu toplumda mümkündür ve her bir birey planlamanın parçasıdır. Aktif toplumlarda kişiye özel, bireysel plan üretilmez. Kişilerin kendi yaşam projeleri ile ilişkili olarak talepleri bulunur, ancak bu taleplerin müzakeresi ile plan yapılabilir.

Aktif yurttaşlıkta katılımcı demokrasi söz konusudur. Burada temsili demokrasi yerine katllımc demokrasi tercih edilebilir Bunun sebebi ise aktif yurttaş temsiliyeti kabul etmek yerine bunun bir parçası olmayı ister ve tüm süreçte yer alır. Temsili demokraside bazı gruplar dışarıda yer alabilir aktif yurttaş bunu kabul etmez. Yönetim farklılıklara önem vermek zorundadır, Sartori (1987), etimolojik demokrasiyi incelediği kitabında sınırlı çoğunluk yönetimi altında bu tanımı yapmaktadır. Halk tümüyle çoğunluk artı azınlıktan oluşur. Kısacası azınlık hakları demokratik süreç için zorunlu koşuldur. Azınlığın, kendi hayat projesinin gerçekleştirebilme koşulunu sağlanması gereklidir. Harvey (2008) tarafından tanımlanan kent hakkı ise bireysel değil kolektif bir haktır.

Habermas (1984, 1987), planlama süreci ile ilişkili olarak "ideal bir konuşma durumundan" bahseder. Bu durum, tüm katılımcların kamusal bir ortamda, karşılıklı anlayış içerisinde özgür ve karşılıklı konuşabilme durumudur ve kamusal alanı oluşturan da budur. Bireyler özelinde tanımlanan bu süreç, kurumlar ölçeğinde yönetişim olarak tartışılabilir. Planlama strateji yapma, karar verme, onaylama ile bir yönetişim biçimidir. Healey (1997), strateji yapma siyasalarını ve tekniklerini iki yaklaşımla incelemektedir. Birincisi bilimsel teknolojiyi geliştirerek karmaşık, bileşik, kamu politikaları bağlamında strateji yapmaya çalışan temsili demokrasilerdeki akılcı süreç yaklaşımı. İkincisi ise, bilginin etkin olarak üretildiği, işi dışarıdan izlemek yerine sürece müdahil olarak işin öğrenildiği, daha bilinçli, bilgili, deneyim paylaşılan ve müzakere edilen etkileşimli yaklaşımdır.

Bu durumda, doğru planlama anlayışı müzakereci planlama anlayışındaki gibi olmalı yani etkileşimli müzakereci bir süreç söz konusu olmalıdır. Planlamada, yerel yönetimler sürekli esneklik sağlayacak bir planlama anlayışı geliştirmelidir. Bu noktada asıl soru kim nasıl müzakere edecek sorusudur. Müzakere platformu açık şeffaf bir müzakereye olanak verecek şekilde oluşturulmalıdır. Bütün stratejik kararlar topluma emrivaki halinde verilemez. Plan topluma emrivaki olarak dayatılan bir şey değildir. Toplumda emrivaki olup olmaması toplumda huzur olup olmaması ile doğrudan ilişkilidir. Katılımcı sü- 
reçlerde insanlar hayal kurabilir ütopya üretebilirler. Önemli olan ütopya üretmeye açık hale gelmektir. Kolektif hareketler, her yerellik kendi ütopyasını üretir. İnsanlar genellikle sıkıntılarını dile getirmek için kolektif harekette bulunurlar. Ancak bir aradalık ve beraber iş yapma becerileri beraberinde meşruiyeti de getirmektedir.

Tekeli katılımcllık sürecinin örgütlenmesinin ve katılımcllı̆ın tanımlanma biçiminin aktif yurttaşlardan oluşan bir toplumda çok önemli olduğunu belirtir. Öncelikle katılımcllı̆̆ın neyi gerçekleştirmeye çalıştığına açıklık kazandırmak gerekecektir. Katılımclığın başarılı olması için sürecin özenli olarak planlanması gerekmektedir. Aktif yurttaş katılımcllı̆ı olarak tanımlanabilecek bir durumda katılımclardan beklenen belli bir çıkarın temsilcisi olmaktan çok, ele alınan konuyla ilgili yeterli adanmışlığ1 (commitment) olan, yeterli bilgiye sahip, yenilikçilik kapasitesi olan, birlikte bir iş yapmanın coşkusunu bölüşebilen bir kişi olmasıdır (Tekeli, 2016, ss. 182-183). Bu bağlamda bir çıkarı olmayan katılımcı sürecin bir parçası olur.

Pasif veya aktif yurttaşlardan oluşan farklı toplum yapılarında ortaya çıkabilecek planlama süreçlerine ilişkin yukarıda ortaya koyulan tartı̧maları sonuçlandırırken, bir planlama problemi üzerinden tartışmayı somutlaştırmak yerinde olacaktır. Pasif yurttaşların yer aldığı bir kentte, kent merkezine yapılacak müdahaleler gibi bir planlama süreci sorun tespitinden başlayarak uygulama sonrasındaki izleme sürecine kadar aktif yurttaşların yaşadığı bir kentteki planlama sürecinden tamamen farklı olacaktır.

Örneğin, Ankara gibi bir kentte kent merkezinin temel problemi motorlu taşıt trafiğinin rahatlatılması olarak tanımlandığında, pasif yurttaşların bu problem tanımına herhangi bir tepkisi olmayacaktır. Şöyle ki, kent merkezinin temel problemi motorlu taşıt hareketi olarak tanımlandığında, planlama süreci içerisinde bilgi de tanımlanan probleme göre toplanmakta, analizler de bu yönde yapılmaktadır. Yapılan analizler sonucunda ise kent merkezinin tamamen motorlu taşıt trafiğine göre yeniden planlanması, kent merkezinde battıçıktı olarak bilinen alt geçitlerin yapılması planlama sürecinin sonucu olarak ortaya çıkmaktadır. Zamanla, kent merkezinde yayalara ait mekânlar azalmaya başlamakta, yayaların üst veya alt geçitlere mahkûm olması beklenilmektedir. Ancak, yapılan tüm bu müdahaleler rağmen hala kent merkezindeki trafik probleminin giderek artmasının önüne geçememektedir (Öncü, 2009, ss. 10-11). Ankara kentinde, ulaşım planlaması kararlarının uygulanması sonrasında izleme ve geri dönüşlerin yapılabileceği aşamalarda bile herhangi bir tepki oluşmamıştır. Bu şekilde işleyen planlama sürecinde pasif yurttaşların 
aktifleşebildiği tek nokta, kendi mülkiyet haklarına yönelik yapılacak müdahaleler noktasında ortaya çıkabilmektedir. Diğer tüm planlama süreçlerinde pasif yurttaşlar tasarlanan, planlanan, uygulanan ve yeniden problem yaratan süreçlere razı olmaktadır.

Eğer, Ankara aktif yurttaşların çoğunlukta olduğu bir kent olsa idi, kent merkezinin planlama sürecinin başka bir yönde ilerlemesi olası olabilecekti. Aktif yurttaşlıkta, planlama sürecinin ilk aşamasında, problem tanımında bir grup motorlu taşıt trafiğinin rahatlatılmasını temel problem olarak ortaya koyduğunda, başka bir grup kent merkezindeki yaya hareketliliğine vurgu yapabilirdi. Başka birileri ise kamusal mekânların korunmasının gerekliliğini vurgular, işlevsel çeşitliliklerden ve deneyim alanlarının çoğaltılması gerektiğini söyleyebilirdi. Bu durumda, planlama sürecinin ilk aşaması olan problem tanımından başlayarak tüm süreçlerin bir müzakere süreci olması beklenebilir.

Aktif yurttaşların yer aldığı bir toplumda, liderler ancak ortaya koyabildikleri vizyonları ile kendileriyle ayn hayalleri paylaşan kişilere liderlik edebilirler. Liderin inandığından başka bir hayat projesi olan kişiler, kendileri için başka mücadele ve müdahale alanları geliştirmek isteyebilir. Bu durumda, aktif yurttaşların içinde yer aldığı bir toplumda demokratik bir lider herkese kendi yaşam projesini hayata geçirmek için eşit olanakları sağlamak ile mükelleftir. Bu durumda, farklı beklentileri olan farklı ilgi gruplarından oluşan aktif bir toplumda, problem tanımından başlayarak analizlerin yapılması, stratejilerin belirlenmesi, planların hazırlanması, uygulanması ve uygulama sonuçlarının değerlendirilmesi, izlenilmesi süreçlerinin her biri bir müzakere süreci olacaktır. Ancak, böyle bir müzakere ortamında yaşanılabilir kent merkezlerinin oluşmasına olanak sağlayacak alternatiflerin tartşılması ve oydaşması olası olabilecektir. Aksi durumda, aktif yurttaşlar zorla dayatılan süreçlere razı olmayacak, sürece katılarak, müdahil olarak sürecin yönlendirilmesinde rol almak isteyeceklerdir.

Aktif ve pasif yurttaşlardan oluşan toplumlarda temel farklılıklar ortaya çıkmaktadır. Bu durumu sadece planlama süreciyle değil plan stratejilerinin uygulanması ve kent bütününde kabul edilmesiyle de ilişkilendirebiliriz. Yerel kurumların kapasitelerinin yüksek olmasının yanı sıra, kentlinin de beraber iş yapabilme becerileri, gündelik hayat ilişkileri ve karşılıklı toplumsal güvenin yüksek olması gibi etmenler ile plan kararlarının uygulanabilirliği ve benimsenmesi kolaylaşmaktadır.

Örneğin, Türkiye'de tarihi kent merkezlerinde yapılan farklı ölçeklerdeki kentsel koruma pratiklerinin uygulanması ve yaygın etkisinde problemler ortaya çıkmaktadır. Ancak, Gaziantep tarihi kent merkezinde kurumsal altyapı 
ve yerel halk iş birliği ile gerçekleştirilen koruma uygulamalarının yaygin etkisi diğer örnekler ile karşılaştırıldığında daha net anlaşılabilmektedir. Gaziantep Büyükşehir Belediyesi kentsel koruma uygulamalarına İlçe Belediyelerinin, Vakıfların, ÇEKÜL'ün ve Koruma Bölge Kurulunun etkin katılımını sağlarken yerel halk ve esnafın da süreci sahiplenebilmesine olanak sağlamıştır. Bu nedenle yapılan koruma uygulamaları kentli tarafından kabul edilmiş, benimsenmiştir (Belge, 2012).

Bu çerçevede değerlendirilebilecek güncel en iyi örnek ise, İzmir Tarih Projesi olarak karşımıza çıkmaktadır. İzmir Tarih Projesi, İzmir'in tarihi kent merkezi olarak bilinen Kemeraltı ve Çevresi kentsel ve 3. Derece arkeolojik sit alanının bütüncül bir bakış açısıyla ve koruma-kullanma dengesi gözetilerek sağlıklaştırılması ve canlandırılması doğrultusunda İzmir Büyükşehir Belediyesi tarafindan 2013 yılında başlatılmıştır (Tekeli, 2015). Bu projenin tasarlanması sürecinde yurttaşların kente dair endişeleri söz konusudur ve bu durum planlama süreci ve kent için çok olumludur. Bu örnekte hikayesi olan bir vizyon ve planlama süreci söz konusudur. Bu proje de tarihsel süreç ve mekandaki bellek gibi kaygılarla mekansal farklılaşma süreçleri değerlendirilmiş ve bu bağlamda projenin yürütüleceği alt alanlar belirlenmiştir. Sonraki süreçte ise belirlenen alanların korunması ve geliştirilmesine yönelik strateji önerileri geliştirilmiştir. Projede önemli olan ise izlenen süreçte katılımın ne şekilde ve nasıl sağlandığ1dır. Temel amaç ise proje alanının dışarıdan gelen ziyaretçiler için gezilecek bir yer olmaktan çıkarak, alanda yaşayanların gereksinim duyduğu kentsel hizmetlerin ötesinde, aşama aşama "deneyim" (experience) yaşanan bir "yer" (place) olmasının sağlanmasıdır. Katılım sürecinde ise her alt proje için proje alanının özelliklerine uygun (case by case) farklı katılım şemaları oluşturulmuştur. Önemli olan bu şemalarda yalnızca lider, onun çevresi değil aktif yurttaş topluluklarında olduğu gibi; belediye, üniversite mensupları, STK'lar, alt proje alanlarında yaşayan sakinler ve bu alanda faaliyet yapan ya da yapmayı planlayan girişimciler yer almaktadır. Bu çerçeve de yürütülen bir süreç; aktif yurttaşlardan oluşan toplumda yere ilişkin değerler ve hedeflerin üretildiği doğru bir yaklaşım olarak karşımıza çıkar.

\section{Sonuç Yerine}

Bugünün demokrasi anlayışı ile kente dair yapılan her bir müdahale demokratik bir süreç ile gerçekleştirilmelidir. Bu şekilde, katılımcı süreçlerin başarılı olabilmesi için kamu alanına ve kente dair karar verme süreçleri bir aradalık ile mümkün olacaktır. Planlama sürecinde olması gereken ise şeffaf ve özellikle 
yerel katılımın sağlandığı sosyo-mekânsal bir süreç olarak değerlendirilen ve hazırlanan, projeler olmalıdır. Daha açık bir ifadeyle, planlama, mekânı bir nesne gibi değil toplumsal yaşamı ve gündelik pratikleri ile birlikte, mekânı biraradalıkla dönüştürebilecek bir süreç tasarımı olmalı ve "yer" in inşası sağlanmalıdır.

Bu bağlamda, pasif ve aktif yurttaşların var olduğu toplumlarda, meşruiyet, demokrasi, hak, planlama ve plancının rolü tamamen farklılaşacaktır. Bu farklılıklar içerisinde, aktif yurttaşlık bilgi, deneyim, beceri ile bir bütün olarak sosyal kapasite gerektirir. Bu toplum yapısında planlama sürecinin farklılaşması da kaçınılmazdır. Bu durumda, plancının da sadece sentez yapabilen teknik bir personelden çok daha fazla beceriye ve kapasiteye sahip olması gerekir. Plancı sezgisi güçlü olan kişidir. Bu durumda, "plancıya sezgisel bir beceri alanı kalır" ve bu beceri ile plancının yaratıcı olması gerekir. Toplum içerisindeki çok farklı ilgi grupları ve beklentilerini anlayabilmeli, planlama sürecinde arabulucu, danışman, akıllı ve yönlendirici olmalıdır. 


\title{
Extended Abstract
}

\section{Planning Process and the Role of the Planner in Communities of Active and Passive Citizens}

\author{
Züleyha Sara Belge \\ ORCID: 0000-0003-0500-4847
}

The aim of article is to discuss what kind of planning processes could emerge in different community structures consisting of active and passive citizens. Active or passive citizenship, the different social structure created by these citizens, the leadership styles that emerging within this structure, representative or participatory democracy and what kind of planning approaches are the main questions of the article. Discussions on how the social structure differences that emerged based on citizenship affect the legitimacy, implementation, organization and planning process of the plan was developed within the framework of theoretical discussions and evaluations in the courses (Middle East Technical University, City and Regional Planning Doctorate Program) conducted by Prof. Dr. İhan Tekeli. In this context, the method of study is based on defining the basic concepts and comparative evaluation through different cases. As a result of these evaluations, it was observed that different planning and implementation processes occurred in cities with social, economic and cultural accumulation points in relation with urban citizenship. As a result, suggestions have been developed regarding the legitimacy, implementation, organization and what kind of planning process can take place by considering the factors such as different citizen behaviours, social structure and leadership.

Tekeli (2010, ss. 91-92) underlines that human rights are universal and expanding rights bring along responsibilities. In other words, if we are talking about a society or a community, there is the concept of "right". Any action that the individual wants to take can be legitimate with "right". However, citizens should be aware that responsibility will increase with these rights.

Democracy is a political order with the people in government (Giddens, 2000, s. 939). Barber (1995) examined politics as a way of life and stated that 
"strong democracy" is also based on the idea of"self-governing citizens." Democracy is not just goal-oriented, the process must be taken into consideration. The most basic form of citizenship is urban citizenship, considering both population, socioeconomic agglomeration and spatial density. In this case, the ability of urban citizens to be active in urban change and transformation is directly related to their social, cultural and economic life. On the other hand, the ability of urban citizens to be active in the change and transformation of urban space is related to the organization and operation of the planning process, regardless of the above-mentioned relations of the citizen.

According to Tekeli (2016), urban planning is a democracy project. Passive citizen cannot participate into the planning process. As a condition of development plans in Turkey, there is self-interest in the plan are executed debate over property rights suspended processes. To put it more clearly, participation in the planning process is only possible at the end of the planning process, the approval phase. The content of the participation at this point is generally based only on the construction conditions, land use decision or transportation forecasts of the owners of their property and / or neighbouring properties. Another problematic aspect of this process is that public interest, which is the basic principle of the planning process in participation, is ignored. Within the planning area, nobody wants to have social-technical infrastructure such as education facility, park, health facility on their property. However, every property owner prefers to have such social infrastructure in their neighbouring parcel.

An active society, planning occurs through negotiation. Participation continues simultaneously with information gathering and decision making processes, not at the final stage of the planning process. In such an environment, each individual has the right to speak. The concept of right is seen as the legitimate way of what the individual wants to do in a society. Human rights are the highest rights here, and legitimacy comes from here. Strategic planning and democratic planning is possible in this society and each individual is an actor of planning. Individuals have demands related to their own life projects, but plans can be made by negotiating these requests. There is participatory democracy in active citizenship. Habermas $(1984,1987)$ mentions "an ideal speech situation" in relation to the planning process.

While concluding the discussions about planning processes that may arise in different social structures consisting of passive or active citizens, it would be appropriate to embody the discussion over a planning problem. In a city with passive citizens, a planning process, such as interventions to the city center, will 
be completely different from the planning process in a city where active citizens live, from problem determination to post-implementation monitoring.

In a society of active citizens, leaders can only lead to those who share the same dreams with their visions. People with a life project other than the leader believes may want to develop other areas of struggle and intervention for themselves. In this case, in a society of active citizens, a democratic leader is obliged to provide equal opportunities for everyone to realize their own life project.

Every intervention about the city with today's understanding of democracy should be carried out through a democratic process. In this way, in order for the participatory processes to be successful, decision-making processes regarding the public realm and the city will be possible together. What should happen in the planning process should be projects that are evaluated and prepared as a transparent and especially socio-spatial process in which local participation is ensured. To put it more clearly, planning should be a process design that can transform space into a combination of social life and daily practices, rather than an object, and the construction of the "place" should be ensured.

In this context, in societies with passive and active citizens, legitimacy, democracy, rights, planning and the role of the planner will be completely different. Among these differences, active citizenship requires knowledge, experience, skill and social capacity as a whole. In this social structure, the differentiation of the planning process is inevitable. In this case, the planner must have much more skills and capacity than a technical staff who can only synthesize. $\mathrm{S} / \mathrm{He}$ is the person with strong planner intuition. In this case, "an intuitive skill area remains for the planner" and with this skill the planner needs to be creative. They should be able to understand many different interest groups and expectations within the community, and they must be mediators, consultants, smart and guiding during the planning process.

\section{Kaynakça/References}

Barber B. (1995). Güçlü demokrasi, İstanbul: Ayrıntı Yayınları

Bauböck, R. (1994). Transnational citizenship: membership and rights in international migration, Aldershot: Edward Elgar Publishing.

Beetham, D. (1991). The legitimation of power, Macmillan, Londra

Belge, B. (2012). The effects of local conservation capacity to the maintenance of historic city centers as a governance process: Gaziantep and Şanliurfa case study areas, Ph.D. Thesis, METU.

Birch A.H, (1993). The concepts and theories of modern democracy. Routledge, London 
Chambers, L. D. and Taylor, M. A. (2019), Reasons for failure in planning, chambers, L. D. and Taylor, M. A (Der.). Strategic planning: processes, tools and outcomes içinde, Routledge, London

Coleman, S. and Blumler, J. (2009). Introduction: anxiety and optimism about democracy. The internet and democratic citizenship: theory, practice and Policy içinde, Cambridge: Cambridge University Press.

Crick, B. (2004). Politics as a form of rule: politics, citizenship and democracy (p. 67-85). Cambridge: Polity

Getimis, P. and Grigoriadou, D. (2005). Changes in urban political leadership: leadership types and styles in the era of urban governance. Urban governance and democracy içinde (p. 178-199). Routledge, London

Giddens, A. (2000). Sosyoloji. Ankara: Ayraç Yayınevi.

Habermas, J. (1984). The theory of communicative action, Volume-1, Reason and the rationalization of society, trans.by Thomas McCarthy, Beacon Press, Boston.

Habermas, J. (1987). The theory of communicative action, Volume-2, Lifeworld and system, Polity Press, Cambridge, U.K.

Harvey, D. (2008). The right to the city. The City Reader, 6(1), 23-40.

Healey, P. (1997). Collaborative planning, UBC Press

İstanbul Büyükşehir Belediyesi (IBBB) (2009), 1/100.000 Ölçekli İstanbul Çevre Düzeni Planı Raporu, İstanbul.

Martin, R. (1993). A System of rights, Clarendon Press.

Melucci, A. (1996). Challenging codes: Collective action in the information age. Cambridge University Press.

O'Donnell, V. (2006). The influence of the built environment. Readings in Propaganda and Persuasion. Thousand Oaks, CA: SAGE Publications, 213-223.

Öncü, A. (2009). Yetmişli yıllardan günümüze Ankara kent yönetimlerinin ulaşım politikaları ve uygulamaları, Dosya 11-Yerel Yönetimler: Ulaşım ve Su, TMMOB Mimarlar Odası, Ankara Şubesi.

Sarıbay, A. Y. (1994). Siyasal sosyoloji: çözümleme çerçevesi. İstanbul: Der Yayınları.

Sartori, G. (1987). The theory of democracy revisited, Chatham House Publishers

Şahin, K. ve Altun, A. (2019). Kentli vatandaş katılım ölçeğinin geliştirilmesi üzerine, Üçüncü Sektör Sosyal Ekonomi Dergisi, 54(4), 1807-1826.

Tekeli, İ. (1991). İstanbul'un yüz elli ylllk planlama deneyimi üzerine genel bir değerlendirme, Kent Planlaması Konuşmaları, TMMOB Mimarlar Odası Yayınları.

Tekeli, İ. (2009). Akılcı planlamadan bir demokrasi projesi olarak planlamaya, İstanbul: Tarih Vakfi Yurt Yayınları.

Tekeli, İ. (2010) Gündelik yaşam, yaşam kalitesi ve yerellik yazıları, İstanbul: Tarih Vakfı Yurt Yayınları.

Tekeli, İ. (2015) İzmir tarih projesi tasarım stratejisi raporu, İzmir Büyükşehir Belediyesi, İzmir.

Tekeli, İ. (2016) Dünya'da ve Türkiye'de kent-kır karşıtlığı yok olurken yerleşmeler için temsil sorunlan ve strateji önerileri. Ankara: İdealkent Yayınları 